\title{
RELEVO DE MESSENE, DOAÇÃO DE CRÁTERO EM DELFOS E A ICONOGRAFIA CINEGÉTICA
}

\author{
MESSENE RELIEF, CRATERUS' DONATION \\ AT DELPHI AND THE LION HUNTING CONOGRAPHY
}

THIAGO DO AMARAL BIAZOTTO

Universidade Estadual de Campinas ${ }^{1}$

https://orcid.org/0000-0003-4339-1526

RESUMO: Este artigo analisa o assim chamado Relevo de Messene, buscando conectar sua iconografia à descrição de uma caçada entre Alexandre Magno e Crátero registrada por Plutarco. Será argumentado que o relevo pode ter sido comissionado pelo filho de Crátero durante as primeiras décadas do século III a.C., de forma a legitimar sua posição como regente na Grécia.

Palavras-chave: Relevo de Messene; Arte helenística; Alexandre Magno; Caça ao leão; Iconografia cinegética

ABSTRACT: This article analyzes the so-called Messene relief, seeking to connect its iconography with the description of a hunt between Alexander the Great and Craterus recorded by Plutarch. It will be argued

1. Universidade Estadual de Campinas. Trabalho financiado pelo CNPq (141445/2019-0). Este artigo é derivado de minha pesquisa de doutoramento em curso, orientada pelo Prof. Luiz Marques, a quem agradeço, pela orientação e inspiração. Também registro minha gratidão à Profa Patricia Meneses pelo apoio constante. De muito valor foram os comentários dos dois revisores anônimos da revista Potestas, a quem agradeço, pelas correções e sugestões pertinentes. 
that the relief may have been commissioned by Craterus' son during the first decades of the 3rd century BC, in order to legitimize his position as regent in Greece.

Key words: Messene Relief; Hellenistic art; Alexander the Great; Lion hunting; Hunting iconography

[Alexandre], de fato, se desgastava de forma mais estrênua nas campanhas e nas caçadas, angustiando-se e arriscando-se. Chegou ao ponto de um embaixador lacedemônio, que estava ao seu lado enquanto ele abatia um enorme leão, dizer-lhe: "Valentemente, decerto, Alexandre, disputaste o reino com o leão!" Crátero consagrou essa cena de caça em Delfos, com estátuas em bronze do leão, dos cães, do rei combatendo o leão, e dele mesmo, [Crátero], acudindo em socorro do rei; algumas [dessas estátuas foram] esculpidas por Lísipo, outras por Leocares.

Plutarco. Vida de Alexandre. 40.3-4²

\section{INTRODUÇÃO}

Um relevo em pedra, escavado em Messene, na região do Peloponeso, é uma das fontes capitais para o estudo da iconografia cinegética no período helenístico. Diversos estudiosos têm encampado esforços para identificar os personagens presentes na obra, quase sempre evocando a supracitada venatória entre Alexandre e Crátero, mas também por vezes chamando à ação figuras menos afamadas, como Poliperconte e Filíades. Embora possua fortuna crítica mais reduzida que seus pares, como o Sarcófago de Alexandre ou o Mosaico de Pela, o chamado Relevo de Messene não pode ter diminuída sua importância para a análise das cenas de caça produzidas na virada do século IV para o III a.C. Afora os aspectos formais, a relevância da recepção

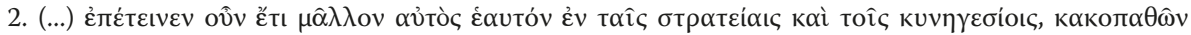

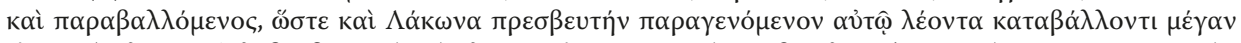

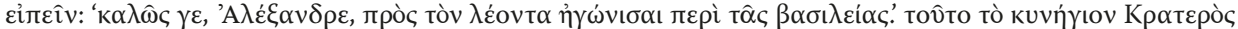

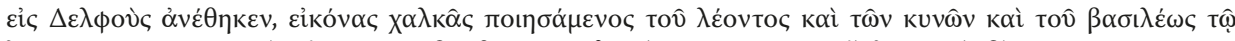

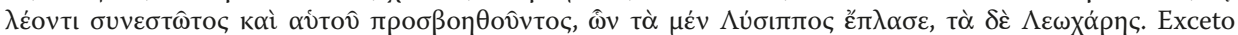
quando houver indicação contrária, todas as traduções são de minha responsabilidade. Para situar o trecho de Plutarco no âmbito da campanha asiática de Alexandre, ver Pierre Briant: "Les chasses d'Alexandre". Ancient Macedonia, nº 5, 1993, pp. 267-77. 
desse tema em um território historicamente hostil a Alexandre, como era o Peloponeso, é dado de primeira grandeza. Assim, este estudo se presta à análise iconográfica da obra, às interpretações mais percucientes aventadas por seus estudiosos e, por fim, a uma tentativa de identificação de seus participantes e motivações de sua comissão.

\section{RELEVO DE MESSENE E SEUS ELEMENTOS ICONOGRÁFICOS}

A história da descoberta do relevo remonta à Expédition scientifique de Morée, missão francesa que trabalhou no antigo sítio de Messene em 1828. A equipe encontrou apenas uma escultura durante a campanha, escavada no gymnasium da cidade e transportada para Paris "par ordre du gouvernement français" ${ }^{3}$. A Restauração não parecia muito distante do Império no que diz respeito à pirataria de material arqueológico, de modo que a peça foi logo posta sob a tutela do Louvre, onde se encontra até hoje (MA858) [Figura 1].

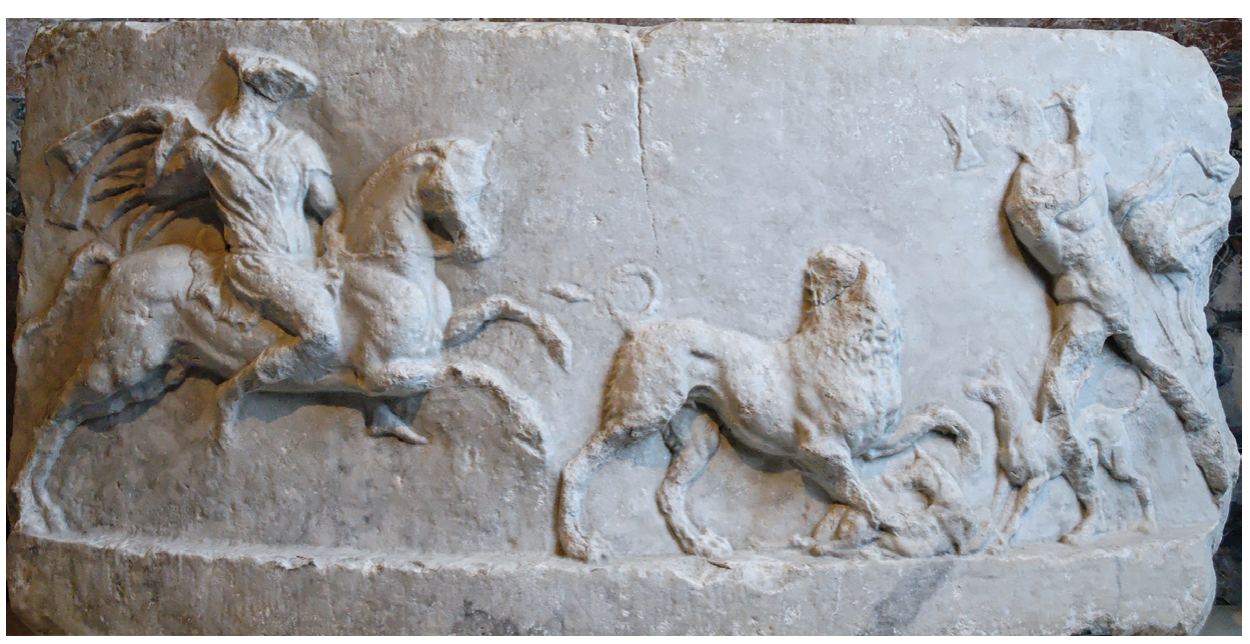

Figura 1: Desconhecido, Relevo de Messene, c.280 a.C. Relevo em pedra, 0,60m de altura, 1,20m de comprimento e 0,28m de profundidade, Louvre, Paris. Disponível em: https://commons.wikimedia.org/wiki/File:Alexander_hunt_Louvre_Ma858.jpg (acesso: 14/09/2020)

3. Apud Petros Themelis: "A Macedonian Horseman - the Relief Louvre, inv. $\mathrm{n}^{\circ}$ MA 858 from Messene". In: Hans Goette (org.): EXCELLENCE. Studies in honour of Olga Palagia. Rahden: Leidorf, 2019, p 169. 
A obra é um bloco de pedra, com $0,60 \mathrm{~m}$ de altura, 1,20m de comprimento e $0,28 \mathrm{~m}$ de profundidade, decorada com relevo responsável por figurar bela cinegética leonina. A partir da esquerda, um cavaleiro irrompe a composição. Trajado com peças do vestuário macedônio - clâmide, chíton de mangas curtas amarrado à cintura e kausia - o caçador montado mira sua lança no leão. Ocupando posição central na cena, o felino esmaga com as patas dianteiras um mastim, que se esforça em levantar a cabeça apenas para ser abatido de forma definitiva. O modo como a fera domina o friso é digno de nota. À parte sua posição centralizada, a brutalidade com que vence o cão é notável, e mesmo o outro mastim, que avança de encontro ao felino a partir da direita, também parece destinado a perecer sob suas patas.

O movimento corporal do leão é o esforço mais notável da venatória. Toda a compleição leonina se projeta à frente - a atenção da fera parece concentrada nos mastins que a açoitam e no segundo caçador, que avança em sua direção. No último instante, porém, o felino parece se dar conta do cavaleiro que avança às suas costas, promovendo torso extraordinário ao voltar seu pescoço para trás, vislumbrando a morte que vem a cavalo. Mesmo os danos ao relevo - minorados pelo preciso desenho de G. Löschke[Figura 2]- não impedem de apreciar a formidável figuração leonina, que retorce seu corpo em pathos de terror face à morte que se assemelha às cenas da Tumba II de Vergina e do Mosaico de Pela.

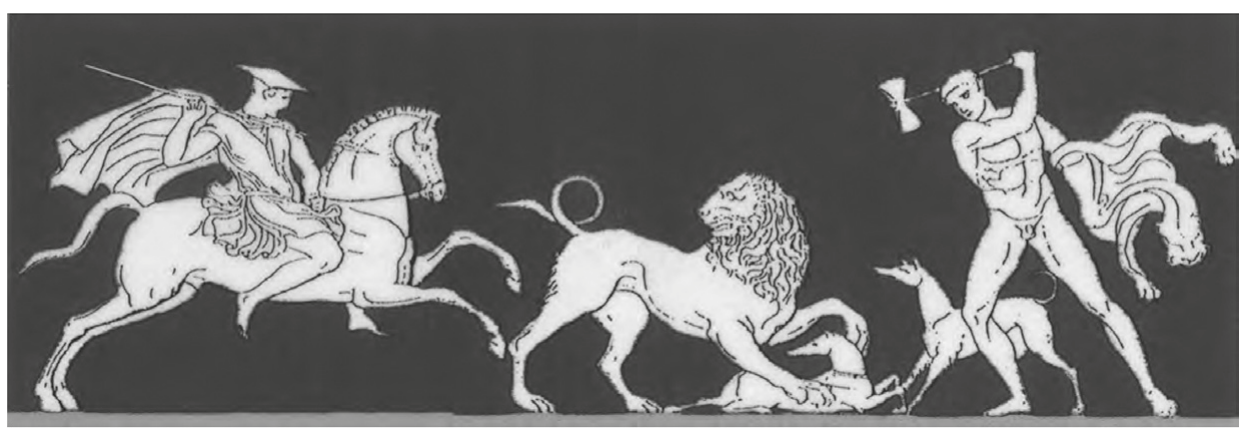

Figura 2: Desenho de G. Löschke, Relevo de Messene, c. 300-280 a.C. Relevo em pedra, $0,60 \mathrm{~m}$ de altura, $1,20 \mathrm{~m}$ de comprimento e $0,28 \mathrm{~m}$ de profundidade, Louvre, Paris. Extraído de: Petros THEMELIS: "A Macedonian Horseman - the Relief Louvre, inv. nº MA 858 from Messene". In: Hans Goette (org.): EXCELLENCE. Studies in honour of Olga Palagia. Rahden: Leidorf, 2019, p 170 
A última figura do relevo é o caçador à direta. Retratado nu, com musculatura avantajada, ele porta no braço esquerdo uma pele leonina. Somada à sua privilegiada compleição, o escalpo do felino aparenta fazer menção a Hércules. Assentadas com firmeza, as pernas dão sustentação necessária para tensionar o braço direito atrás de seu pescoço. O machado duplo, que porta à destra, parece ser a arma destinada a desferir o coup de grâce no leão que mantém sob mira.

Ainda que sumária, esta ekphrasis logra elencar elementos centrais do relevo. Aspectos como o assalto ao leão por dois caçadores distintos, o uso do machado duplo, o torso e o pathos leonino, o cavaleiro que assoma à composição a partir da esquerda, o uso dos cães, entre outros, aparecem também em outras obras mais celebradas, como os já mencionados Mosaico de Pela e friso da Tumba II de Vergina, o que documenta a importância do fragmento peloponésio para o exame da circulação da iconografia cinegética durante os séculos IV e III a.C.

\section{RELEVO DE MESSENE: DA HISTORIOGRAFIA À IDENTIFICAÇÃO DOS PERSONAGENS}

Aspecto central no estudo do Revelo de Messene é a identificação de seus personagens. Para esse labor, com frequência é lembrada a doação de Crátero em Delfos, cujo programa iconográfico figuraria o general salvando Alexandre durante uma cinegética leonina, conforme a passagem já citada de Plutarco, e outra, mais sucinta, de Plínio (NH 34. 64): "Lísipo é notável por ter esculpido a flautista embriagada (...) fez, da mesma forma, a caçada de Alexandre, a qual está consagrada em Delfos" (nobilitatur Lysippus et temulenta tibicina [...] Idem fecit Alexandri venationem, quae Delphis sacrata est).

Um dos primeiros a estabelecer essa vinculação foi Paul Perdrizet ${ }^{4}$. Em 1898, o arqueólogo francês elenca três obras que poderiam retratar a venatio Alexandri citada por Plutarco: Sarcófago de Alexandre, Medalhão de Tarso

4. PAUl Perdrizet: “Communication: La Venatio Alexandri à Delphes”. Bulletin de Correspondance Hellénique, vol. 22, pp. 566-569, 1898. Ainda no século XIX, foi encontrado, em Delfos, o epigrama original da doação de Crátero, assinado por seu filho: O filho de Alexandre, Crátero, dedicou isto (a Apolo)/Um homem exaltado, honrado e afamado/Entregou (contudo), seu filho Crátero, a quem ele gerou no palácio e deixou quando criança/Cumprindo com todas as promessas de seu pai/Para lhe trazer glória, doce e eterna, ó estrangeiro/Como caçador daquele leão devorador de touros/Pois quando uma vez ele seguiu Alexandre/E destruiu tudo com ele/Com aquele aclamado rei da Ásia, ele o feriu com ele e o matou/Quando ele caiu em

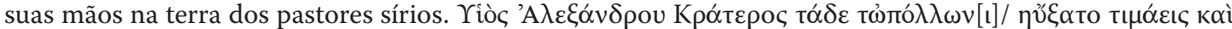
$\pi о \lambda v ́ \delta$ о

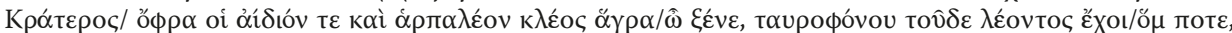

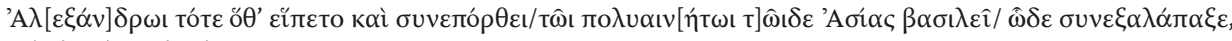

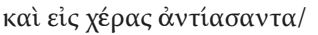

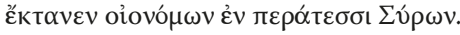

Texto grego extraído de (https://epigraphy.packhum.org/text/240270?hs=384-389). Acesso: $10 / 12 / 2020$ 
e o próprio Relevo de Messene. Perdrizet, entretanto, propõe que nenhuma delas figura o caçador real em perigo ("ne nous montre le royal chasseur en danger"). De fato, mesmo ponderando que Lísipo e Leocares morreram antes da inauguração do monumento, concluído apenas sob a supervisão do filho de Crátero, Perdrizet considera improvável que ambos os escultores retratassem Alexandre à mercê dos leões, o que criaria dificuldade metodológica na conexão entre texto e imagem nesse episódio.O autor retomou o assunto em estudo publicado um ano depois. Como não poderia ser diferente, replica muitas de suas teses, reforçando que, no Relevo de Messene, o leão parece correr mais riscos do que o caçador ${ }^{5}$.

Entre os comentaristas do fragmento escultórico, texto importante é o do catálogo The Search for Alexander: An Exhibition. Montada a reboque da descoberta das tumbas de Vergina, a exposição rodou por alguns dos mais famosos museus americanos: National Gallery, Art Institute of Chicago, Museum of Fine Arts e The Fine Arts Museums of San Francisco. Publicado 1980, o volume estampa na capa os nomes de Nicholas Yalouris (Inspetor Geral de Antiguidades da Grécia), Katerina Rhomiopoulou (Diretora Museu Arqueológico de Tessalônica) e ninguém menos que Manolis Andronikos. Embora a obra de Messene não tivesse circulado com a exposição, sua ficha consta do catálogo.

O verbete inicia destacando que a estátua seria pequeno fragmento oriundo de complexo programa iconográfico, no qual diversas cinegéticas se entrelaçariam. Após descrição breve - que destaca kausia, clâmide e chíton vergadas pelo cavaleiro- o catálogo propõe tese tão assertiva que merece ser analisada na íntegra:

A caça não-mitológica ao leão ingressa na arte grega com Alexandre, o Grande. Ele e seu séquito devem ter praticado esse perigoso passatempo nos famosos parques do antigo Império Persa; a caçada com Crátero é mencionada tendo lugar na Síria, e caçada de Sídon de Alexandre e o rei Abdalônimo, no Sarcófago de Alexandre, é explicitamente oriental em seus pormenores, bem como suas localizações, com a maior parte de seus participantes em traje persa. Como um caçador de leões real, atacando com a lança as bestas, montado em seu cavalo, Alexandre adotou a iconografia juntamente com o esporte dos reis do Antigo Oriente Próximo ${ }^{6}$.

Tradução a partir de ANDREW STEWART: Faces of Power: Alexander's Image and Hellenistic Politics. Berkley: University of California Press, 1993, p. 409. Para breve histórico da descoberta do epigrama, ver: THÉOPHILE Homolle: "La chasse d'Alexandre". Bulletin de Correspondance Hellénique, n 21 , pp. 598-600, 1897.

5. PAul Perdrizet: “Venatio Alexandri”. The Journal of Hellenic Studies, vol. 19, 1899, p. 277.

6. "The nonmythological lion hunt enters Greek art with Alexander the Great. He and his retinue must have practiced this dangerous pastime in the celebrated game parks of the former Persian Empire; the hunt with Krateros is referred to as taking place in Syria, and the Sidonian hunt of Alexander and King Abdalonymos on the Alexander Sarcophagus is explicitly Oriental in accouterments as well as locale, with most 
Algumas passagens do trecho podem causar certa surpresa, quando são recordadas hipóteses anteriores defendidas por seus autores. Ao afirmar que o repertório da cinegética leonina ingressou na arte grega após Alexandre, o texto desdiz tese que Andronikos defendeu durante toda a vida: a de que a Tumba II de Vergina abrigaria Filipe II, pai do conquistador.

Na sequência, ao classificar a caça aos leões conduzida a cavalo como passatempo perigoso, a passagem repercute - talvez de forma voluntária - trecho do Cinegético, de Xenofonte (11.1-3). Nele, o autor ático também emprega o ter-

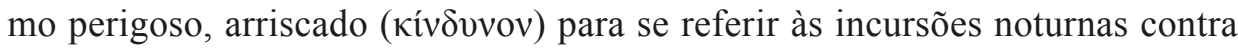
leões capturados em terras estrangeiras(év $\xi \dot{\varepsilon} v \alpha 1 \varsigma \chi \omega ́ \rho \alpha 1 \varsigma)$. O texto do catálogo -ainda que não conte com identificação explícita dos autores responsáveis por cada passagem - e Xenofonte não têm dúvida do quanto as venatórias a cavalo contra os felinos eram alienígenas aos costumes gregos antes do advento de Alexandre.

O trecho final é notável ao sublinhar que o conquistador passou a fazer uso tanto do esporte da caça quanto de sua iconografia, ambos típicos dos monarcas asiáticos, tendo o cuidado de perfilar todos seus apanágios: o uso do paradei$s o s$, grandes parques artificiais destinados à caçada, que abrigavam vasta fauna e flora, a montaria, o uso da lança, as incursões coletivas e o leão como presa maior. Após rotular a obra de Messene como pertencente ao período helenístico inicial, o catálogo propõe que o relevo é possível eco da comissão de Crátero a Lísipo e Leocares, cujo modelo teria se tornado eminente já na Antiguidade, garantindo-lhe inúmeras cópias. Destarte, Alexandre assumiria o papel do caçador à direita, enquanto o veterano acudiria em socorro, vindo montado à esquerda.

Stewart, antecipado por Anderson ${ }^{7}$ e sucedido por Seyer ${ }^{8}$, segue essa proposta, embora afirme que o estado de conservação do relevo não permite vislumbrar o diadema de Alexandre, peça que forneceria o argumento fatal para sua identificação com o caçador a pé. Defendendo a datação da obra entre 300-275 a.C., Stewart aponta que, tanto quanto o episódio de Crátero, a iconografia do relevo traria particular impacto junto à audiência de Messene por sua alusão a Hércules e ao leão de Nemeia: se no contexto mitológico Iolau era sempre retratado diante da besta com desamparada impotência ("helpless impotence"), aqui sua contraparte histórica, Crátero, seria prodi-

participants in Persian dress. As a royal lion hunter, spearing the beasts from his horse, Alexander adopted the iconography along with the sport of ancient Near Eastern kings". Manolis Andronikos (ed.) et alli: The Search for Alexander: an exhibition. Columbus: Little, Brown and Company, 1980, pp. 121-22.

7. JoHn Kinloch Anderson: Hunting in the Ancient World. Berkley: University of California Press, 1985, p. 79.

8. MARTIN SEYER: “The Royal Hunt - The Symbolic Meaning of an Ancient Topos.” In: Armin PRINZ (ed.): Hunting Food and Drinking Wine:Proceedings of the XIXth Congress ofthe International Commission for the Anthropology of Food (ICAF), Poysdorf, Austria Dec. 4-Dec. 7, 2003. Vienna: Transaction Publishers, 2006, pp. 185-6; 188. O mesmo autor enfatiza a sutileza iconográfica do Relevo de Messene, no qual Alexandre, caçador montado, não aparece em desvantagem frente ao leão. 
gioso em salvar a vida de seu mestre. A obra do Louvre, portanto, seria cópia do monumento comissionado pelo general' ${ }^{9}$.

Stewart é mais refinado ao relacionar o relevo ao cenário político dos diádocos. No final do século IV a.C., a região do Peloponeso estava sob o domínio de Antígono Monoftalmo, responsável por fundar a dinastia antígona em 306 a.C. De acordo com passagem de Plutarco (Plut. De Frat. 15), o filho de Crátero, responsável por concluir a doação do grupo cinegético em Delfos, teria se estabelecido em Corinto por volta de 280 a.C., com cerca de 40 anos de idade, lá permanecendo até sua morte, duas décadas mais tarde. Como quer Stewart, não seria de espantar que Crátero Filho estivesse em contato contíguo com os antígonas, talvez atuando como conselheiro real, graças à sua linhagem privilegiada. Aproveitando sua posição, Crátero teria encomendado a cópia do retrato honorífico a seu pai, mesmo em sítio periférico em relação aos demais reinos helenísticos ${ }^{10}$.

Palagia também responde por interpretação sofisticada. A primeira observação da arqueóloga diz respeito à materialidade do objeto: ao invés de uma base de estátua, Palagia crê que o fragmento pertença a um monumento funerário (tholos), do qual seria parte de relevo mais elaborado, com diversas cenas de caça. Após identificar as vestes macedônias do cavaleiro à esquerda, Palagia se recusa a aceitar a ligação entre o relevo e o episódio de Crátero, em particular a identificação de Alexandre com o caçador a pé. A autora grega acredita que o personagem seria melhor identificado como bárbaro. A hipótese é que a figura retrataria integrante da tribo indiana dos Tibi, que reclamavam ascendência de Hércules e usavam peles de animais como vestimenta, conforme passagens de Quinto Cúrcio (9.4.2-3) e Arriano (Ind. 5.12). Alexandre, tampouco, poderia estar representado no cavaleiro, à ausência do diadema e do chíton oriental, de modo que a figura seria algum dos companheiros do conquistador.

É nesse ponto que a tese de Palagia se torna mais burilada. A autora retoma Poliperconte, general que lutou sob Filipe II e Alexandre, mas que assumiu papel algo secundário na guerra dos diádocos ${ }^{11}$. Após arrogar a regência da Macedônia em 319 a.C., acabou deposto por Cassandro três anos depois, vindo buscar refúgio no Peloponeso e tomando o controle de Messene até o início do século III a.C. (Diod. 20. 28. 1-4; Plut. Pyrrh. 8. 3). Poliperconte, ademais, era delegado de Crátero ao menos desde 324 a.C., sendo, portanto, familiar à doação que o general ofereceu em Delfos (Arr. Anab. 7.12.4).

9. STEWART: Op. Cit., pp. 274-7; 427.

10. Idem, pp. 281-2.

11. O que talvez explique sua longevidade: nascido por volta de 390/380 a.C., acredita-se que Poliperconte viveu até o início do século III a.C. Detalhes de sua trajetória podem ser encontrados em: WINTHROP LINDSAY ADAMS: "Alexander's Successors to 221 BC". In: JOSEPH ROISMAN, \& IAN WORTHINGTON: A Companion to Ancient Macedonia. Wiley: Blackwell, 2010, pp. 208-224. 
Desejoso por emular Crátero, lastreado por sua regência, conquanto breve, da Macedônia, Poliperconte visava a perpetuar as campanhas na Índia, nas quais teve destaque. Vale lembrar que Quinto Cúrcio (9.1.32-33) atesta a presença de caçadas ao leão naquele território, dado que forneceria o cheque-mate do argumento: o relevo seria parte do tholos de Poliperconte, figurado a cavalo em terras indianas e acompanhando por um autóctone, à direta da composição $0^{12}$.

Anos mais tarde, Palagia reiterou sua tese, em artigo escrito em conjunto com Eugene Borza. Qualificando a obra como enigmática, os autores iniciam apontando os trajes envergados pelo cavaleiro, além de rotularem a figura à direita como caçador profissional ("professional hunter"). Após datarem o relevo peloponésio dos anos iniciais do século III a.C., Borza e Palagia repetem os argumentos, desta vez acrescentando a informação de que Demétrio Poliócertes conduziu campanha contra Messene, possivelmente tendo Poliperconte como alvo (Plut. Demetr. 33.2) ${ }^{13}$.

Cohen estipula a datação do relevo entre 320-318 a.C., defendendo que, em algum momento do século III a.C, ele foi empregado como base de um grupo escultórico. Do ponto de vista iconográfico, a autora aduz que o caçador à direta, por sua compleição e uso da pele leonina, adquire contornos míticos, com claras menções a Hércules. Cohen é proficiente em traçar os pioneiros em relacionar a cena ao episódio venatório de Alexandre e Crátero. Com efeito, a identificação do conquistador com a figura a pé, e do general como o cavaleiro, teve Loeschcke como precursor (1888), ao passo que a tese contrária foi aventada por Wolters e Sieveking, cerca de 20 anos depois (1909). A historiadora americana não se aventura a relacionar o episódio textual e a iconografia do relevo, contudo ${ }^{14}$. Publicado no mesmo ano do estudo de Cohen, o capítulo de Sawada opta por datação dilatada do artefato - final do século IV a início do III a.C. -, além de defender tratar-se de possível encomenda de algum dos sucessores de Alexandre, que, por fim, encerra a iconografia cinegética leonina entre os diádocos ${ }^{15}$.

12. Olga Palagia: "Hephaestion's Pyre and the Royal Hunt for Alexander". In: Brian Bosworth \& Elizabeth Baynham (orgs.): Alexander the Great in Fact and Fiction. Oxford: Oxford University Press, 2000, pp. 202-6.

13. Eugene Borza \& Olga PAlagia: “The chronology of the Macedonian royal tombs at Vergina”. Jahrbuch des Deutschen Archäologischen Instituts, n 122, 2007, p. 98.

14. AdA COHEN: Art in the Era of Alexander the Great: Paradigms of Manhood and their Cultural Traditions. Cambridge: Cambridge University Press, 2010, pp. 76-78. Também não aventam a possibilidade de conexão PIERRE BRIANT: "Chasses royales macedoniennes et chasses royales perses: le theme de la chasse au lion sur la Chasse de Vergina”. Dialogues d'historie ancienne, $\mathrm{n}^{\circ}$ 17, 1991, p. 224; HALliE FranKS: Hunters, Heroes, Kings: The Frieze of Tomb II at Vergina. Rome: American School of Classical Studies, 2012, p. 36 e Víctor Alonso Troncoso: "The Zoology of Kingship from Alexander to the Epigoni (336 - C. 250 BC). Anabasis: Studia Classica et Orientalia, n 5, 2014, p. 36.

15. NORIKO SAWADA: "Social Customs and Institutions: Aspects of Macedonian Elite Society”. In: JOSEPH RoISMAN \& IAN WorTHINGTON: A Companion to Ancient Macedonia. Wiley: Blackwell, 2010, p. 400. 
Petros Themelis é autor do último estudo monográfico sobre o fragmento. Reputado por conduzir diversas campanhas arqueológicas em Messene, o grego propõe nova identificação dos personagens. Suas primeiras ponderações dizem respeito à materialidade do objeto. Ao contrário da maioria de seus antecessores, Themelis não considera o relevo parte de uma base de estátua: ao contrário, ele seria componente de um longo friso, com cerca de $5,5 \mathrm{~m}$ de diâmetro e complexo programa iconográfico ${ }^{16}$.

Para sustentar a hipótese, Themelis cita outro fragmento, em pedra, mantido no reserva técnica do Museu de Messene, que pertenceria ao segundo bloco do mesmo friso da cinegética (inv. $\mathrm{N}^{\circ} 501$ ). O que nele se tem preservado é o torso de um veado ou antílope ferido que, por critérios formais, o arqueólogo atribui ao mesmo mestre responsável pelo relevo de caça, o que reforça a suposição de venatória com múltiplas presas. Dessa forma, ambos os fragmentos pertenceriam a um edifício circular, com emprego sagrado ou funerário ${ }^{17}$.

Themelis relembra que construções circulares eram usualmente erigidas na forma de santuários a Hércules. Além de figura de proa no Peloponeso, era de praxe evocar o herói como protetor de efebos nos ginásios gregos, de maneira que diversas inscrições dedicatórias a Hércules foram encontradas nesse tipo de edifício. Uma delas é de particular importância para Themelis. Cravada em uma herma, descoberta próxima à colunata do ginásio de Messene e datada do princípio do século III a.C., ela forneceria pista fundamental para a identificação

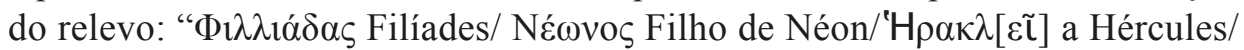

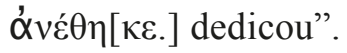

Segundo o arqueólogo grego, o Filíades em exame era descendente de segunda geração de conhecida família de Messene. Já Néon e seu irmão Trasíloco eram membros do partido pró-Macedônia na região, sendo caracterizados como traidores por Demóstenes na Oração da Coroa (295) e recebendo adjetivos também não muito simpáticos da parte de Políbio (18.14.3). Themelis propõe que tanto a matéria-prima usada no Relevo de Messene - a pedra, ao invés do suntuoso marfim - quanto o estilo austero da herma de Hércules revelam a produção dos dois por ateliê local. Ambos teriam pertencido a um mesmo monumento, construído intra muros no ginásio de Messene e usado como local de enterro dos membros da família de Filíades. Embora seja cético com respeito às relações entre o relevo e o episódio de Crátero, Themelis conclui seu estudo sem arriscar identificação dos personagens da cinegética $^{18}$.

16. THEMELIS: Op. Cit, p. 170.

17.Idem, p. 171-2.

18.Idem, pp. 174-175. 
Este breve apanhado demonstra como a identidade dos participantes da caçada de Messene segue em aberto. De fato, o próprio sítio virtual do Louvre não é categórico em sua atribuição. Além de classificar a cena apenas como dita caçada de Alexandre ("chasse dite d'Alexandre"), o texto afirma, no máximo, ser possível querer reconhecer ("on a voulu reconnaítre") a figura do conquistador, assimilado a Hércules, à direita da cena. Crátero, vindo em socorro, seria o cavaleiro ${ }^{19}$. Frente a essas inúmeras controvérsias, é de bom tom apresentar, no próximo segmento, a proposta de atribuição adotada neste artigo

\section{RELEVO DE MESSENE: HIPÓTESE DE IDENTIFICAÇÃO DOS PERSONAGENS}

A proposta aqui é mobilizar argumentos em prol da seguinte identificação: Alexandre como cavaleiro à esquerda e Crátero como caçador com o machado duplo à direita. Esta hipótese será alicerçada em três argumentos: o elevado número de figurações de Alexandre a cavalo, o uso da kausia no relevo e a importância da presença de Crátero Filho em Messene no início do século III a.C.

Como observou Moreno, o cavaleiro que irrompe a partir da esquerda é uma "convenzione orientale", que se popularizou não somente no início do período helenístico, mas, sobretudo, nos retratos do próprio conquistador ${ }^{20}$. Exemplos não faltam: Mosaico de Alexandre, friso A do Sarcófago de Alexandre, as ânforas de Apúlia, além das emissões numismáticas.

Seria desacertado, contudo, acreditar que essa figuração era inaudita na arte grega anterior a Alexandre. Como notou Miller, a iconografia dos vasos áticos já havia se escorado nesse filão ${ }^{21}$. Um dos primeiros exemplos é uma copa, pelo Painter of the Oxford Brygos, datada c. 480 a.C ${ }^{22}$.Tendo como tema a guerra entre gregos e persas, à luz dos conflitos coevos, a historiadora destaca a pre-

19. (http://cartelfr.louvre.fr/cartelfr/visite?srv=car_not_frame\&idNotice $=20688 \&$ langue $=\mathrm{fr}$ ). Acesso: 10/12/2020. A página, infelizmente, não nomeia o autor do verbete.

20. PAOlo MORENO: "Immagini di Alessandro Magno: monete e storia”. In: RoSElla PERA: Il Significato delle Immagini: Numismatica, Arte, Filologia, Storia. Roma: Giorgio Bretschneider Editore, 2012, p. 159. O mesmo fenômeno foi observado por Frank Holt, embora sem atinar à procedência oriental dessa figuração. Ver FrANK HOLT: Alexander the Great and the Mistery of the Elephant Medallions. Berkley, Los Angeles \& London: University of California Press, 2003, pp. 126; 131. No mesmo sentido, GIUliana CALCANI: Cavalieri di bronzo: la torma di Alessandro opera di Lisippo. Roma: L’Erma di Bretschneider, 1989, pp. 47-8; 147.

21. Margaret Miller: "Persians in the Greek Imagination". Mediterranean Archaeology, vol. 19/20, 2006/07, pp. 113-14.

22. Copa de figuras vermelhas, fragmentada, procedente de Care (Etrúria). Datação c. 490-480 a.C. Diam. 32,8 cm, ARV 399; Oxford 1911.615. A respeito do mesmo artefato, ver: ANTHONY BARRETT \& MICHAEl VICKERS: “The Oxford Brygos Cup Reconsidered”. The Journal of Hellenic Studies, vol. 98, pp. 17-24, 1978; MANEL GARCÍA SANCHÉZ: El Gran Rey de Persia. Formas de representacíon de la alteridad persa en el imaginario griego. Barcelona: Universidad de Barcelona, 2009, p. 307. 
cisão do pintor em retratar o armamento aquemênida e também em conduzir o olhar do espectador no sentido horizontal, na orientação esquerda/direita. Ao segui-la, argumenta Miller, Brygos teria como intuito retratar o avanço vitorioso ("victorious advance") do exercício grego, sem, entretanto, menoscabar os persas.

Não obstante, o que se quer pôr em relevo neste momento é que Alexandre e seu círculo de artistas foram responsáveis por ampliação desse modelo. Antes empregado apenas em cenas de guerra, a fórmula do cavaleiro que avança pela esquerda passou com frequência à iconografia cinegética, decerto se valendo de seus antecessores asiáticos. Nesse sentido, não é exagero afirmar que o conquistador foi responsável por criar, no âmbito do mundo grego, a imagem do rei-caçador ("re-cacciatore"), como defende Tripodi ${ }^{23}$.

Subscrevendo a observação do historiador italiano, é possível argumentar em favor da identificação de Alexandre com o cavaleiro caçador do relevo a partir do cruzamento de sua figuração com a de muitas outras do conquistador. Este cotejo é válido tanto para imagens de batalha, com a do Mosaico de Alexandre [Figura 3], friso A do Sarcófago de Alexandre [Figura 4], ânforas de Apúlia $^{24}$, Medalhão de Poro ${ }^{25}$, entre outros, como de caça, bem representadas pela Tumba II de Vergina [Figura 5], Mosaico de Palermo ${ }^{26} \mathrm{e}$, em especial, friso B do Sarcófago de Alexandre [Figura 6]. Mesmo na venatória leonina a pé, retratada no Mosaico de Pela [Figura 7], Alexandre também é visto, amiúde, como o caçador à esquerda.

23. BRUNO TRIPODI: "Il fregio della caccia della II tomba reale di Vergina e le cacce funerarie d'Oriente". Dialogues d'histoire ancienne, no 17, 1991, p. 175.

24. Conjunto de ânforas de figuras vermelhas, pelo pintor de Dario. Museo Nazionale, Nápoles, Itália (inv. $n^{\circ}$ 81947). Datação: c. 330 a.C. Ver: MARIE-Christine VillanueVA-Puig: "Le Vase des Perses. Naples 3253 (inv. 81947)”. Revue des Études Anciennes, vol. 91, n¹-2, pp. 277-298, 1989.

25. Conjunto de medalhões, em prata, cunhados por volta de 325-320 a.C., e cuja iconografia carrega o embate entre Alexandre o rajá indiano Poro. Talvez a peça mais emblemática do conjunto esteja no British Museum (inv. $\mathrm{n}^{\circ}$ 1887,0609.1). Ver o importante estudo de FrANKS: Op. Cit.

26. Mosaico datado de c. século II a.C., possível cópia de pintura helenística original do século IV a.C., com o tema da caçada a cavalo a múltiplas presas - leão e javali. Casa B da Piazza della Vittoria (Palermo), in situ. Ver: William WOOTTON: "Another Alexander mosaic: reconstructing the Hunt mosaic from Palermo". Journal of Roman Archeology, vol. 15, pp. 264-274, 2002. 


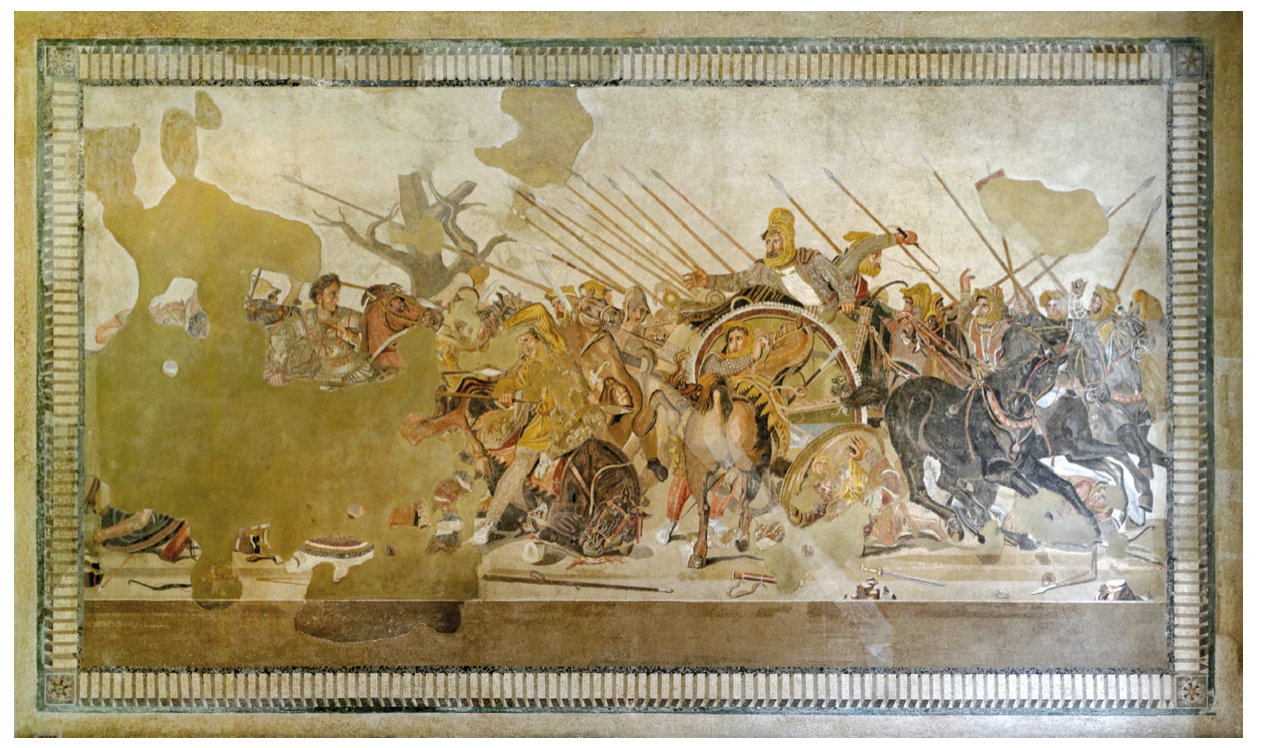

Figura 3: Cópia romana de Filóxeno de Erétria (?), Mosaico de Alexandre, original c. 330-310 a.C., cópia c. 120-100 a.C. Mosaico de seixos, $271 \mathrm{~cm}$ de altura, $512 \mathrm{~cm}$ de comprimento, Museu Arqueológico Nacional, Nápoles. Disponível em: https:// en.wikipedia.org/wiki/Alexander_Mosaic\#/media/File:Battle_of_Issus_mosaic_-_Museo_ Archeologico_Nazionale_-_Naples_2013-05-16_16-25-06_BW.jpg (Acesso: 14/09/2020)

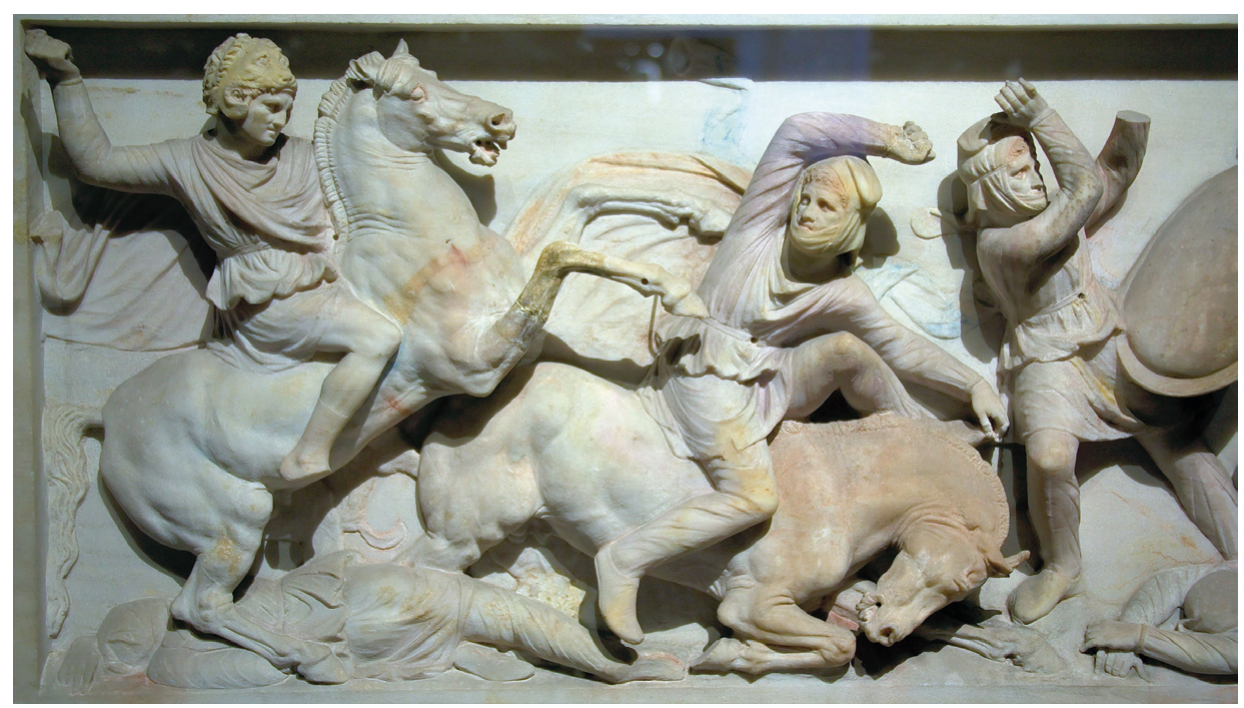

Figura 4: Desconhecido, Sarcófago de Alexandre (detalhe do friso A), c. 300 a.C. Escultura em mármore pentélico, $195 \mathrm{~cm}$ de altura, $318 \mathrm{~cm}$ de comprimento, $167 \mathrm{~cm}$ de profundidade, Museu Arqueológico de Istambul, Istambul. Disponível em: https://commons.wikimedia. org/wiki/File:Alexander_Sarcophagus_Battle_of_Issus.jpg (Acesso: 14/09/2020) 


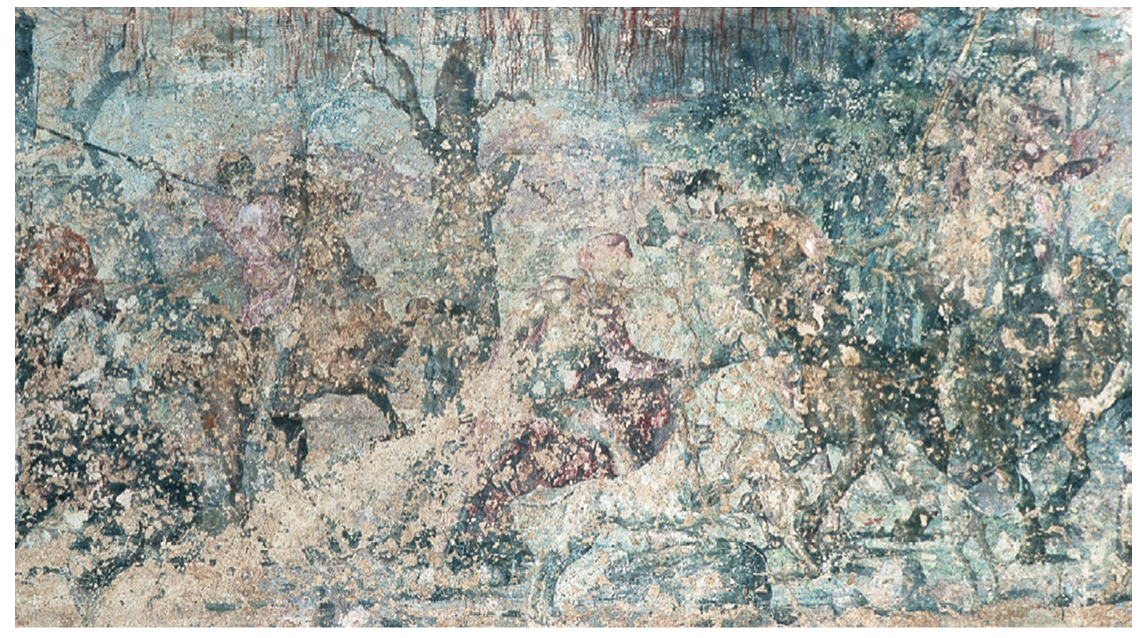

Figura 5: Desconhecido. Tumba II de Vergina (detalhe da caça ao leão, Alexandre é a primeira figura à esquerda), c. 330-300 a.C. Afresco, $116 \mathrm{~cm}$ de altura, $556 \mathrm{~cm}$ de comprimento, Museu das Tumbas Reais, Vergina. Extraído de: HALLIE FRANKS: Hunters, Heroes, Kings: The Frieze of Tomb II at Vergina. Rome: American School of Classical Studies, 2012, p. 7

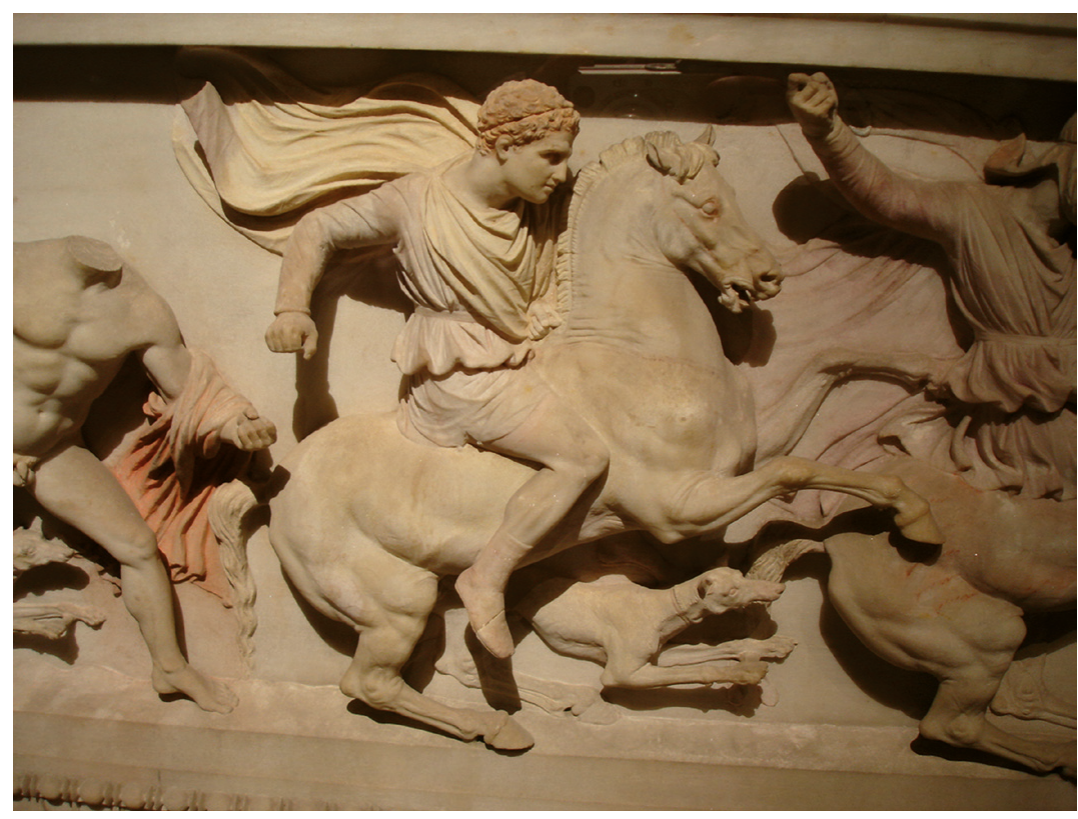

Figura 6: Desconhecido, Sarcófago de Alexandre (detalhe do friso B), c. 300 a.C. Escultura em mármore pentélico, $195 \mathrm{~cm}$ de altura, $318 \mathrm{~cm}$ de comprimento, $167 \mathrm{~cm}$ de profundidade, Museu Arqueológico de Istambul, Istambul. Disponível em: https://commons.wikimedia. org/wiki/File:Istanbul_-_Museo_archeol._-_Sarcofago_di_Alessandro,_sec._IV_a.C._-_ Foto_G._Dall\%27Orto_28-5-2006_08.jpg (Acesso: 14/09/2020) 


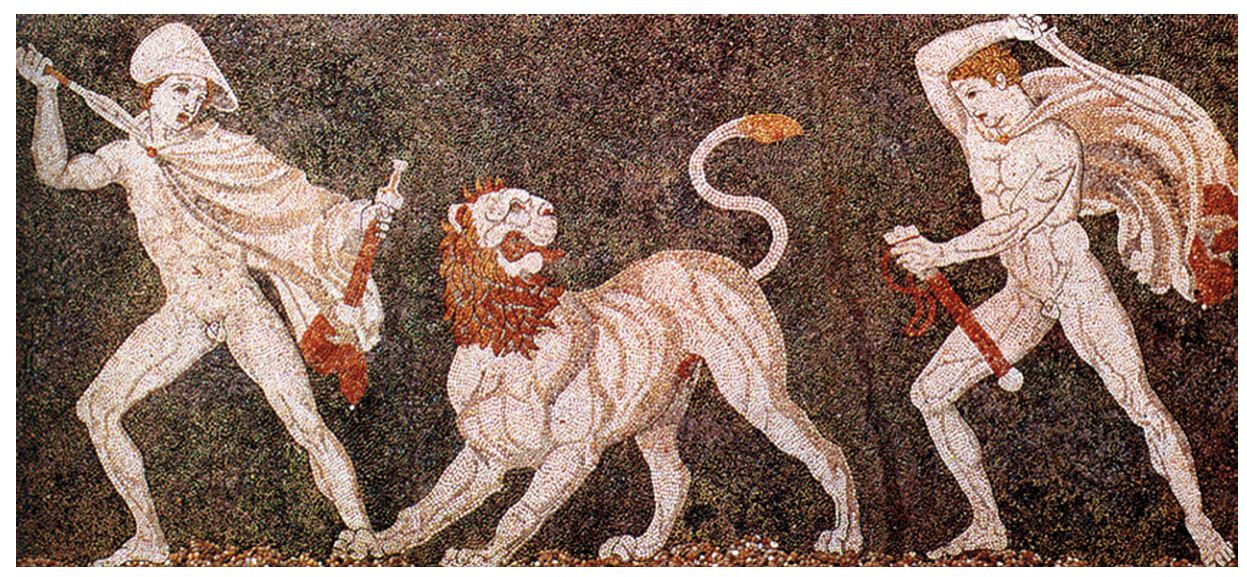

Figura 7: Desconhecido, Mosaico de Pela c. 300 a.C. Mosaico de seixos, $317 \mathrm{~cm}$ de altura, $324 \mathrm{~cm}$ de comprimento. Museu de Pela, Pela. Disponível em: https://commons.wikimedia. org/wiki/File:Lion_hunt_mosaic_from_Pella.jpg. (Acesso: 14/09/2020).

O segundo ponto diz respeito à kausia vergada pelo caçador montado. A descoberta das tumbas de Vergina provocou intenso debate sobre a peça. Em 1981, Bonnie Kingsley deu início aos trabalhos, propondo que a kausia macedônia era derivada de um tipo de touca chamada chitrali, usada até os dias atuais no Paquistão e Afeganistão, sobretudo na província do Nurestão ${ }^{27}$. Segundo a autora americana, não havia registros da kausia na iconografia ou literatura grega antes de 325/4 a.C., de modo que o artefato foi conhecido no Mediterrâneo apenas após o retorno dos veteranos de Alexandre. Sem embaraço, Kingsley afirma que apenas atinou à semelhança entre kausia e chitrali ao ver fotos de combatentes afegãos na revista Time.

Kingsley enumera a primeira menção à peça na literatura grega: uma passagem de Arriano, na qual Alexandre, após retornar da Índia, veste a kausia, amarrando o diadema em seu entorno, possivelmente em alusão à realeza da Pérsia que havia conquistado.O trecho é saboroso: o conquistador navegava sozinho pelo Eufrates, próximo a uma região pantanosa na qual se localizavam

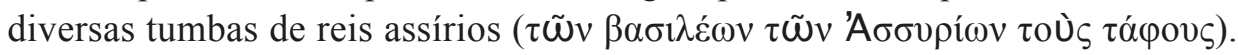
Alexandre, porém, foi surpreendido por um golpe de vento, que atingiu sua kau-

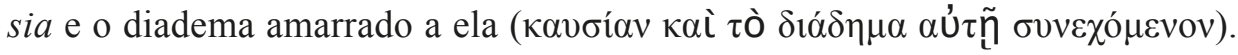
Mais pesada, a kausia afundou na correnteza, enquanto o diadema foi levado pelo vento até ficar preso nos juncos que cresciam nas tumbas dos reis locais (Arr. Anab. 7.22.2).

27. Bonnie KINGSLEY: “The Cap That Survived Alexander”. American Journal of Archaeology, vol. 85, 1981 , p. 41. 
Fragmento de Éfipo de Olinto, historiador que acompanhou a expedição de Alexandre, é também evocado por Kingsley. Citado por Ateneu, o passo afirma que os trajes diários de Alexandre consistiam da clâmide, do chíton e da kau-

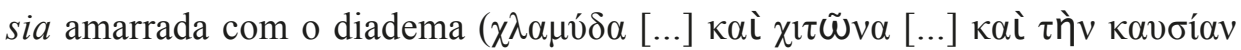

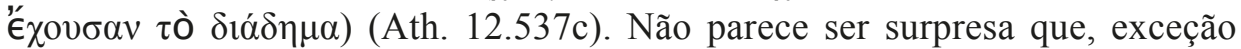
feita ao diadema, todas as demais peças estão presentes no caçador montado de Messene.

A kausia tornou-se atributo real tão característico que o primeiro dos reis helenísticos autoproclamados, Demétrio Poliórcetes, passou a fazer uso da peça por volta de 286 a.C. (Plut. Demet. 41.6). De fato, o próprio Crátero foi outro dos veteranos a envergá-la. Em outro excerto de Plutarco (Eum. 6.1.), o biógrafo relembra a grande popularidade de Crátero junto ao exército macedônio, bastando que a soldadesca visse a kausia usada pelo general e ouvisse a sua voz

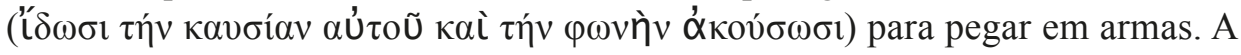
partir do século III a.C., a associação entre os macedônios e a kausia tornou-se lugar comum. Um comediógrafo como Plauto pôde empregar a forma latinizada causea em diversas de suas peças, além do Idílico (15.6), de Teócrito, mencioná-la como acessório típico dos exércitos ptolomaicos.

Três anos após a publicação original, Kingsley voltou ao tema ${ }^{28}$. Além de reforçar que nenhum rei macedônio havia usado a peça antes de Alexandre, a arqueóloga pontua que dois companheiros do conquistador, Crátero (Plut. Eum. 5.1-3) e Onesícrito (Estrabão 15.1.64), passaram a usar a kausia durante a expedição na Índia, sendo possível estipular o inverno de 327/6 a.C. como a data em que o acessório foi usado pela primeira vez por ocidentais. Dadas as relações umbilicais entre a kausia e Índia, Kingsley especula que a touca de Alexandre poderia tê-lo caracterizado como conquistador local, um novo Dioniso.

A primeira oposição sistemática às teses de Kingsley veio na forma do artigo "Alexander the Great and the Macedonian Kausia", de Ernst Fredricksmeyer ${ }^{29}$. $\mathrm{O}$ autor americano começa revisitando dois documentos textuais a respeito da recusa das tropas macedônias em seguir pelo Rio Hífase, marcando o ponto final da expedição de Alexandre. Em Diodoro (17.94.1-3), os soldados consideram

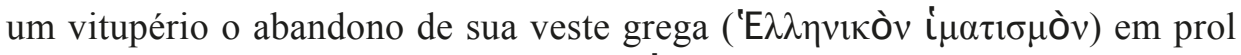
do uso dos trajes bárbaros ( $\beta \alpha \rho \beta \alpha \rho \iota \kappa o \tilde{\iota} \zeta$ Ú $\varphi \alpha ́ \sigma \mu \alpha \sigma$ )), então representados pelos

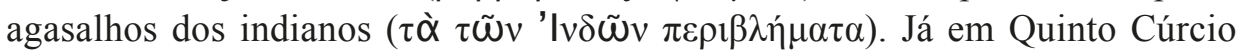
(9.3.10-11), soldado de nome Coenus se dirige a Alexandre vexado por ver a si próprio e seus companheiros vestidos em trajes persas (Vestem Persicam induti), que os teria reduzido a meros replicadores dos costumes estrangeiros (in externum degeneravimus cultum). Ambos os trechos, fundamentais na argu-

28. BonNIE KIngSLEY: “The Kausia Diadematophoros”. American Journal of Archaeology, vol. 88, pp. $66-68,1984$

29. ERnSt FREDRICKSMEYER: "Alexander the Great and the Macedonian Kausia”. Transactions of the American Philological Association, vol. 116, 1986, pp. 217-8. 
mentação de Kingsley, são revisados por Fredricksmeyer. Ao recordar que, na passagem de Diodoro, os soldados reclamam estar usando trajes estrangeiros

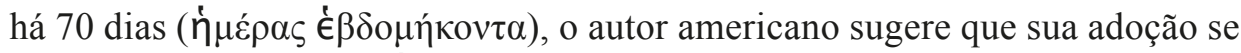
deu antes da chegada às Índias

Fredricksmeyer também reúne dossiê de passagens textuais que comprovariam a kausia como peça tradicional do vestuário macedônio. Para ficar apenas nos exemplos mais à mão, Polieno (5.44.5) menciona a kausia macedônica

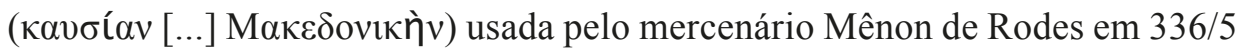
a.C., cuja presença na corte de Filipe II foi atestada por Diodoro (16.52.3). Já Plutarco, em sua biografia de Eumenes (8.7), relata que o tesoureiro de

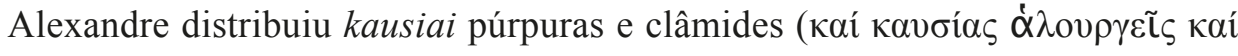
$\chi \lambda \alpha \mu v \delta \delta \varsigma$ ) entre seus aliados, por serem presentes régios tradicionais entre os

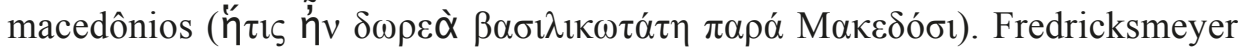
conclui que Alexandre, ao reunir a tradicional kausia macedônia ao diadema típico dos persas, deu à luz criação sui generis, assumindo papel muito mais complexo do que o de simples sucessor de Dario III $^{30}$.

Em 1991, Kingsley respondeu às críticas feitas por seu colega, em novo artigo $^{31}$. Se Fredricksmeyer havia dito que o debate em torno da kausia era pouco mais que querela de antiquário, a autora denuncia a ingerência dessa assertiva, afirmando tratar-se decontenda de primeira grandeza no auxílio à datação de diversas obras. Com efeito, Kingsley passa a listar uma série de kausiai no repertório helenístico. No Mosaico de Alexandre, a figura de perfil ao lado do braço direito do conquistador, usualmente identificada com Ptolomeu, usaria o acessório, assim como um dos caçadores da Tumba II de Vergina, mormente identificado como Cassandro.

Para o caso que nos interessa, Kingsley afirma que o Relevo de Messene figura a kausia no cavaleiro da cena. De resto, a arqueóloga americana insiste na importância da tradição oriental na peça, com direito a fotos de populações do Hindu Kush que usariam modelo idêntico àquele que inspirou seu par macedônio, além de arrolar 18 testemunhos textuais que ratificariam sua tese ao mesmo tempo em que refutam as de Fredricksmeyer ${ }^{32}$.

Em longo artigo publicado em 1993, Prestianni Giallombardo sorveu as hipóteses basilares de Kingsley. A historiadora emprega a maior parte de seus esforços em identificar possíveis kausiai no friso da Tumba II de Vergina, de modo a provar a importância asiática em sua iconografia e, portanto, a datação posterior à expedição de Alexandre. A italiana é enfática ao destacar o acessório como apanágio régio, assim como salientar o papel do basileu em investir-lhe majestade, uma vez que os textos falam: "geralmente da kausia como um gor-

30.Idem, 227.

31. BONNIE KingSLEY: “Alexander's 'Kausia' and Macedonian Tradition”. Classical Antiquity, vol. 10, pp.59-76, 1991.

32.Idem, pp. 72-4. 
ro não difundido e popular, mas, acima de tudo, real, tanto porque é trazido, primeiro, por Alexandre, o rei, para a Ásia ou adotado por seus sucessores quando assumem o título de basileis "33. De resto, Prestianni Giallombardo vislumbra duas kausiai no friso da tumba, no sexto e nono caçadores a partir da esquerda, provas de que o último quartel do século IV a.C. é o único período em que a peça poderia existir e circular na Macedônia ${ }^{34}$.

Saatsoglou-Paliadeli, discípula de Andronikos, publicou o último estudo relevante a respeito ${ }^{35}$. Ainda enlutada pela morte de seu mestre, a arqueóloga grega dedica seu artigo à memória Andronikos - de resto, Saatsoglou-Paliadeli o acompanhava no momento da descoberta das tumbas de Vergina ${ }^{36}$. Para o caso de interesse deste estudo, a autora é uma das únicas a negar a presença da kausia no Relevo de Messene. Embora leve em conta os danos ao cavaleiro da obra, Saatsoglou-Paliadeli propõe que o contorno semicircular do chapéu pode pertencer à borda de um petasos e não a qualquer tipo de barrete, o que inviabilizaria quaisquer conexões entre o fragmento e o episódio de Crátero e Alexandre.

Como visto, a historiografia é quase consensual em atestar a presença da kausia no cavaleiro do Relevo de Messene. Diante da fisionomia régia da qual o acessório estava imbuído, torna-se mais viável associá-lo à figura que representaria Alexandre no artefato peloponésio ${ }^{37}$. Somando ao uso da kausia pelo conquistador, documentado por Arriano e Éfipo de Olinto, temos argumento a favor da identificação aqui proposta.

A última justificativa se relaciona à presença do filho de Crátero em Corinto no início do século III a.C., citada por Plutarco. Rebento de Crátero e Fila, Crátero Filho teria nascido por volta de 320 a.C., pouco antes da morte de seu pai. Após enviuvar, Fila se casa com Demétrio Poliórcetes. Os dois seriam pais de Antígono Gônatas (nascido em 319 a.C.), um dos mais importantes diádocos e, portanto, meio-irmão de Crátero Filho (Diod. 19. 59.3; Plut. Dem. 14.2; Plut. De Frat. 15). Acredita-se que o possível comitente tenha recebido educação de primeira qualidade na corte dos Antigônidas, permanecendo fiel à casa, com possível participação militar em momentos cruciais do período helenístico

33. "in genere della kausia corne di un copricapo non diffuso e popolare, ma innanzitutto regale, sia perché è portato, primo fra tutti, da Alessandro re in Asia o adottato dai suoi successori quando assumono il titolo di basileis". ANNA MARIA PRESTIANNi GIALlOMBARDO: "Recenti testimonianze iconografiche sulla kausia in Macedonia e la datazione del fregio della caccia della II tomba reale di Vergina”. Dialogues d'histoire ancienne, vol. 17, 1991, p. 262.

34.Idem, p. 286.

35. Chryssoula SaAtsoglou-Paliadeli: "Aspects of Ancient Macedonian Costume". The Journal of Hellenic Studies, vol. 113, pp. 122-147, 1993.

36. ANDRONIKOS: Op. Cit, p. 26.

37. Reconhecida, de resto, pelo próprio dicionário Liddell/Scott, que dá ao verbete a seguinte conotação: chapéu de feltro usado pelos macedônios, parte constituinte dos acessórios reais de seus monarcas. "Felt hat used by the Macedonians, forming part of the regalia of their kings". HENRY LIDDELL \& ROBERT SCOTT: A Greek-English Lexicon. Oxford: Oxford Univesity Press, 1996, p. 932. 
inicial, como a Batalha de Ipso (301 a.C.). Ademais, como aponta Billows, Crátero Filho não era apenas o braço direito de Antígono Gônatas - atuando como governador da Grécia, lotado em Corinto, entre c. 280 - 260 a.C. - mas também compilador de decretos atenienses, erudito que exercia a mais nobre das ocupações - a de historiador ${ }^{38}$.

Fica patente como estamos falando de figura notável, que unia tino político e profunda erudição, atributos indispensáveis para sobreviver em meio à guerra dos diádocos. O elevado repertório do regente, e em particular seu papel na conclusão do grupo escultórico de Delfos, tornam sedutora a hipótese de conectar Crátero Filho ao Relevo de Messene, como possível comitente de obra que, conquanto em menores proporções, lembrasse o feito, ao mesmo tempo em que exaltava a nobreza de sua linhagem e sustentava seu posto como figura axial no Peloponeso.

Admitindo-se a pertinência desta tese, é possível mobilizar outra série de argumentos. Em primeiro lugar, autores como Stewart e Palagia alegarem que a falta do diadema torna improvável a ligação entre Alexandre e o caçador a cavalo $^{39}$. O dano causado à cabeça do cavaleiro poderia ter destruído o acessório, e não é possível mesmo descartar sua subtração por ladrões, já que muitas vezes o diadema, feito em ouro, era um dos principais alvos de pilhagens - o Alexandre do friso B do sarcófago de Sídon é o exemplo mais evocativo. À parte essa possibilidade, Crátero Filho, de apurado senso político, não poderia negligenciar as relações sempre tensas entre Alexandre, e por consequência seus generais, com os peloponésios, em particular, os espartanos.

Para mencionar apenas dois exemplos, Plutarco (Alex.16.8) conta que Alexandre, após a vitória em Grânico, enviou butim de 300 escudos tomados do inimigo a Atenas, com inscrição sintomática: "Alexandre, filho de Filipe, e todos os gregos - exceto os lacedemônios - (tomaram) dos bárbaros que habitam

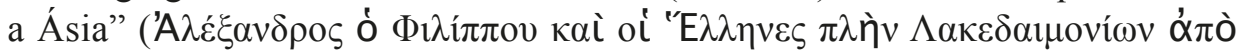

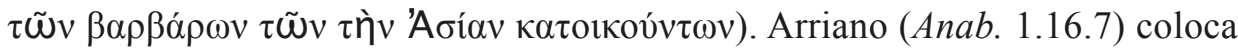
a doação de Alexandre nos mesmos termos. Embora possa haver sutil ironia na doação de Alexandre, envolvendo a rivalidade entre Atenas e Esparta e mesmo os 300 de Leônidas, a atitude do conquistador parece clara retaliação à falta de suporte lacedemônio para a expedição asiática. Outra amostra é a sublevação do rei espartano Ágis III (r. 338-331 a.C.), que declarou guerra contra a hegemonia de Alexandre em 331 a.C., logrando sitiar Megalópolis até ser derrotado

38. RiCHARD BILlOWS: Antigonos the One-Eyed and the Creation of the Hellenistic State. Berkley: University of California Press, 1997, pp. 396-7, com todas as fontes. A argumentação é de Billows; a galhofa é minha. Para a atuação profissional de Crátero Filho, ver CAROLYN HigBiE: "Craterus and the Use of Inscriptions in Ancient Scholarship". Transactions of the American Philological Association, vol. 129, pp.

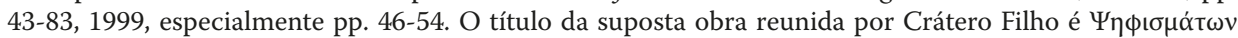

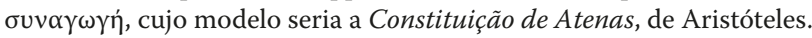

39.Stewart: Op. Cit., pp. 274-7; 427; Palagia: Op. Cit., pp. 402-3. 
por Antípatro, um dos generais do basileu (entre outros, ver: Diod. 16. 63,68; Curt. 6.1 e Arr. Anab. 2.13).

Crátero Filho, como potencial comitente do Relevo de Messene, não poderia passar despercebido pelas sevícias enfrentadas pela memória de Alexandre no território em que era regente. Isso, somando à postura conservadora de seu pai, que com frequência denunciava os atributos orientais adotados pelo conquistador, poderia tê-lo levado a ocultar de modo proposital o diadema de sua encomenda ${ }^{40}$. A mirada em acessório estigmatizado como próprio do fausto dos reis da Ásia poderia provocar, no potencial expectador da obra, flagelo e ressentimento ainda maior com relação à figura de Alexandre e, por extensão, mesmo a dos Cráteros pai e filho ${ }^{41}$.

Essa sequela, decerto, não ajudaria em nada a sustentar o poder, sempre instável, de um regente helenístico como Crátero Filho. Nesse sentido, a kausia - de possível origem oriental, mas nem de longe tão condenada quanto o diadema persa - talvez fosse suficiente para identificar Alexandre como o cavaleiro de Messene, dado o caráter real ínsito à peça.De fato, o próprio Crátero se paramentava com o acessório, o que poderia suavizar sobremodo sua presença para um público potencialmente contrário à política oriental capitaneada por Alexandre.

Outro dado fulcral na identificação proposta é a figuração peculiar do caçador pedestre. Sua musculatura e pele leonina, notáveis atributos de Hércules, tornam-se ainda mais relevantes quando se recorda as relações entre o herói, a instituição ginasial e o local de descoberta do relevo, demonstradas por Themelis $^{42}$. A se aceitar a identificação da figura com Crátero, seria possível vislumbrar sofisticada estratégia política por trás da comissão de seu filho. Ao retratar seu pai como autêntico sucessor de Hércules, o regente de Corinto conseguiria, ao menos, três vantagens: granjear simpatia junto ao público de Messene, ao mostrar sua linhagem à semelhança de Hércules, figura peloponésia por excelência; sustentar seu comando local graças a essa mesma associação e, por fim, contrabalancear as tradições asiáticas - neste caso, a caça montada ao leão e o uso da kausia - nas quais Alexandre se locupletava, figurando-o lado a lado com representante do mais pan-helênico dos heróis.

Um último detalhe não pode passar despercebido: o pescoço retorcido do leão em direção ao seu algoz. Como visto ao longo deste artigo, esse pathos é

40. Sobre os aspectos conservadores e patrióticos da personalidade de Crátero, ver BRIAN BOSWORTH: Conquest and Empire: the reign of Alexander the Great. Cambridge: Cambridge University Press, 1988, pp. 134; 157; 175 e 175 nota 5. Lane Fox pôs em relevo a lealdade canina ("doggedly") de Crátero aos costumes macedônios. Ver Robin LANE Fox: Alexander the Great. London: Penguin, 1986 [1973], pp. 325; 429 e 474. Na mesma direção, ver PAUl CARTLEDGE: Alejandro Magno. La búsqueda de un pasado desconocido. Tradução de David León Gómez. Barcelona: Ariel, 2007 [2004], p. 89. Sobretudo, ver: EDWARD ANSON: “The Macedonian Patriot: The Diadoch Craterus". The Ancient History Bulletin, nº 26, pp. 49-58, 2012.

41. Para mencionar apenas uma fonte, Diodoro Sículo (17.77.4-5) menciona que Alexandre, ao fazer uso

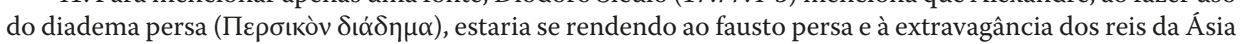

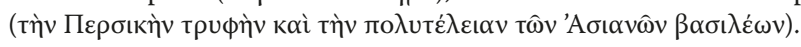

42. THEMELIS: Op. Cit., pp. 173-4. 
convenção iconográfica usada para identificar o verdugo da fera. No caso do Mosaico de Pela, ele estaria consonante com o texto de Plutarco, uma vez que o animal volta-se para Crátero, que corre em socorro de Alexandre. Porém, o inverso ocorre no Relevo de Messene, com o leão voltado à figura identificada com o conquistador. A pergunta inevitável é a que se deve essa mudança. A resposta pode mais uma vez apontar para o público da obra.

Admitindo-se que a caça régia ao leão é tradição asiática importada por Alexandre e seus legatórios, Crátero Filho, ao comissionar relevo que inverte o esquema mais comum das cinegéticas helenísticas, estaria reforçando seu caráter oriental, ao mostrá-la conectada à imagem do conquistador e não a seu pai, sempre resistente aos costumes estrangeiros. Parece haver até certa tensão no Relevo de Messene. Por um lado, Alexandre, montado e caçando como herdeiro das monarquias asiáticas, e, por outro, Crátero, delineado como Hércules, conduzindo a venatória a pé com os cães, à moda grega ${ }^{43}$, e com a nudez heróica interrompida apenas pelo couro leonino que reforça suas ligações com o herói argivo. Embora não sejam conhecidas, ao menos do ponto de vista da tradição textual, conexões contíguas entre Crátero e Hércules, a simetria formal entre a figura mitológica e o caçador nu no Revelo de Messene parecer apontar para motivação política na condução das escolhas iconográficas presentes na obra.

A agência do artefato e a intenção de seu comitente parecem claras: a política oriental conduzida por Alexandre, com sua hýbris intrínseca, é salva graças às sendas tradicionais de um conservador como Crátero - e, por metonímia, seu filho. Crátero Filho, portanto, surge como possível comitente da obra, que poderia ser parte de um monumento funerário, como querem Palagia e Themelis - inclusive o dele próprio ${ }^{44}$.

Assim, se há pertinência na hipótese deste artigo, é possível datar o Relevo de Messene de c. 280 a.C. até 260 a.C., tendo como ponto de partida o início de regência de Crátero Filho em Corinto e sua morte como terminus. Tendo por premissa que o filho de Crátero foi o comitente do artefato, a leitura iconográfica desenvolvida neste texto pauta-se pelas implicações políticas que o artefato teria para com o público do Peloponeso.

43. Do ponto de vista iconográfico, parece tratar-se do cão da Lacônia, mais famosa e importante raça de cães de caça gregos. Para origens e fontes, ver: DENISON HULL: Hounds and Hunting in Ancient Greece. Chicago \& London: The University of Chicago Press, 1964, pp. 31-34.

44. Neste caso, mesmo respeitando as devidas diferenças entre o cenário aqui discutido e aquele de Florença no século XV, é possível evocar uma passagem de Baxandall: "Aquele que encomendava, pagava e definia a utilização a ser dada à pintura poderia ser chamado o mecenas, se nesse termo não estivessem inseridas várias conotações provenientes de outras situações bem diversas. Essa segunda pessoa, na transação da qual a pintura será resultado, é um agente ativo, determinante e não necessariamente benevolente: podemos chamá-lo de cliente. A melhor pintura produzida no século XV era realizada sob encomenda por um cliente que exigia sua execução conforme suas especificações", Michael Baxandall: O Olhar Renascente. Pintura e Experiência Social na Itália da Renascença. Tradução de Maria Cecília Preto R. Almeida. Rio de Janeiro: Paz e Terra, 1991 [1972], p. 11. 


\section{BIBLIOGRAFA}

ADAMS, WINTHROP LINDSAY: "Alexander's Successors to 221 BC". In: ROISMAN, JOSEPH \& Worthington, IAn: A Companion to Ancient Macedonia. Wiley: Blackwell, 2010, pp. 208-224.

AlONSO Troncoso, Víctor: "The Zoology of Kingship from Alexander to the Epigoni (336 - C. 250 BC). Anabasis: Studia Classica et Orientalia, nº 5, pp. 53-75, 2014.

ANDERSON, JOHN KINLOCH: Hunting in the Ancient World. Berkley: University of California Press, 1985.

ANDRONIKOS, MANOlis (ed.) et alli: The Search for Alexander: an exhibition. Columbus: Little, Brown and Company, 1980.

ANSON, EDWARD: "The Macedonian Patriot: The Diadoch Craterus". The Ancient History Bulletin, $\mathrm{n}^{\circ}$ 26, pp. 49-58, 2012.

BARretT, ANTHONy \& Vickers, Michael: “The Oxford Brygos Cup Reconsidered”. The Journal of Hellenic Studies, vol. 98, pp. 17-24, 1978.

BAXANDAll, Michael: O Olhar Renascente. Pintura e Experiência Social na Itália da Renascença. Tradução de Maria Cecília Preto R. Almeida. Rio de Janeiro: Paz e Terra, 1991 [1972].

BILlOWs, RiCHARD: Antigonos the One-Eyed and the Creation of the Hellenistic State. Berkley: University of California Press, 1997.

Borza, EugEne \& PAlagia Olga: "The chronology of the Macedonian royal tombs at Vergina". Jahrbuch des Deutschen Archäologischen Instituts, n 122, pp. 81-125, 2007.

BOSWORTH, BRIAN: Conquest and Empire: the reign of Alexander the Great. Cambridge: Cambridge University Press, 1988.

BRIANT, PIERRE: “Les chasses d'Alexandre”. Ancient Macedonia, no 5, pp. 267-77, 1993.

BRIANT, PIERRE: "Chasses royales macedoniennes et chasses royales perses: le theme de la chasse au lion sur la Chasse de Vergina". Dialogues d'historie ancienne, $\mathrm{n}^{\circ} 17, \mathrm{pp}$. 211-255, 1991.

CAlCANi, GiUliana: Cavalieri di bronzo: la torma di Alessandro opera di Lisippo. Roma: L'Erma di Bretschneider, 1989.

CARTledge, Paul: Alejandro Magno. La búsqueda de un pasado desconocido. Tradução de David León Gómez. Barcelona: Ariel, 2007 (2004).

COHEN, ADA: Art in the Era of Alexander the Great: Paradigms of Manhood and their Cultural Traditions. Cambridge: Cambridge University Press, 2010.

FRANKS, HAlliE: Hunters, Heroes, Kings: The Frieze of Tomb II at Vergina. Rome: American School of Classical Studies, 2012.

FREDRICKSMEYER, ERNST: "Alexander the Great and the Macedonian Kausia". Transactions of the American Philological Association, vol. 116, pp. 215-227, 1986.

GARCía SANCHÉZ, MANEL: El Gran Rey de Persia. Formas de representacíon de la alteridad persa en el imaginario griego. Barcelona: Unversidad de Barcelona, 2009.

HigBIE, CAROLYN: "Craterus and the Use of Inscriptions in Ancient Scholarship". Transactions of the American Philological Association, vol. 129, pp. 43-83, 1999.

HOLT, FRANK: Alexander the Great and the Mistery of the Elephant Medallions. Berkley, Los Angeles \& London: University of California Press, 2003.

HOMOLLE, ThÉOPHILE: "La chasse d'Alexandre". Bulletin de Correspondance Hellénique, no 21, pp. 598-600, 1897.

Hull Denison: Hounds and Hunting in Ancient Greece. Chicago \& London: The University of Chicago Press, 1964.

KIngSley, BONNIE: “Alexander's 'Kausia' and Macedonian Tradition”. Classical Antiquity, vol. 10, pp. 59-76, 1991. 
KINGSLEY, BONNIE: “The Kausia Diadematophoros”. American Journal of Archaeology, vol. 88, pp. 66-68, 1984.

KINGSLEY, BONNIE: “The Cap That Survived Alexander”. American Journal of Archaeology, vol. 85, pp. 39-46, 1981.

LANE FOX, ROBIN: Alexander the Great. London: Penguin, 1986 (1973).

LIDDELL, HENRY \& SCOTT, ROBERT: A Greek-English Lexicon. Oxford: Oxford Univesity Press, 1996.

Miller, MARGARET: "Persians in the Greek Imagination". Mediterranean Archaeology, vol. 19/20, pp. 109-123, 2006/07.

MORENO, PAOLO: "Immagini di Alessandro Magno: monete e storia". In: PERA ROSElla: Il Significato delle Immagini: Numismatica, Arte, Filologia, Storia. Roma: Giorgio Bretschneider Editore, 2012, pp. 153-170.

PAlAGIA, OlgA: "Hephaestion's Pyre and the Royal Hunt for Alexander". In: BOSWORTH, BRIAN \& BAYNHAM, ELIZABETH (orgs.): Alexander the Great in Fact and Fiction. Oxford: Oxford University Press, 2000, pp. 167-206.

PERDRIZET, PAUL: "Venatio Alexandri". The Journal of Hellenic Studies, vol. 19, pp. 273-279, 1899.

Perdrizet, PAUl: "Communication: La Venatio Alexandri à Delphes". Bulletin de Correspondance Hellénique, vol. 22, pp. 566-569, 1898.

PRESTIANNI GIALLOMBARDO, ANNA MARIA: "Recenti testimonianze iconografiche sulla kausia in Macedonia e la datazione del fregio della caccia della II tomba reale di Vergina". Dialogues d'histoire ancienne, vol. 17, pp. 257-304, 1991.

SAatsoglou-Paliadeli, Chryssoula: "Aspects of Ancient Macedonian Costume". The Journal of Hellenic Studies, vol. 113, pp. 122-147, 1993.

SAWADA, NORIKO: "Social Customs and Institutions: Aspects of Macedonian Elite Society". In: ROISMAN, JOSEPH \& WORTHINGTON, IAN: A Companion to Ancient Macedonia. Wiley: Blackwell, 2010, pp. 392-408.

SEYer, MARTIN: “The Royal Hunt - The Symbolic Meaning of an Ancient Topos." In: PRINZ, ARMIN (ed.): Hunting Food and Drinking Wine: Proceedings of the XIXth Congress ofthe International Commission for the Anthropology of Food (ICAF), Poysdorf, Austria Dec. 4-Dec. 7, 2003. Vienna: Transaction Publishers, 2006, pp. 171-198.

Stewart, ANDReW: Faces of Power: Alexander's Image and Hellenistic Politics. Berkley: University of California Press, 1993.

Themelis, Petros: "A Macedonian Horseman - the Relief Louvre, inv. no MA 858 from Messene". In: GoetTe, HANS (org.): EXCELLENCE. Studies in honour of Olga Palagia. Rahden: Leidorf, 2019, pp. 169 - 178.

TRIPODI, BRUNO: "Il fregio della caccia della II tomba reale di Vergina e le cacce funerarie d'Oriente". Dialogues d'histoire ancienne, n 17, pp. 143-209, 1991.

VillanueVA-Puig, MARIE-Christine: "Le Vase des Perses. Naples 3253 (inv. 81947)”. Revue des Études Anciennes, vol. 91, n¹-2, pp. 277-298, 1989.

WoOTTON, WilliaM: "Another Alexander mosaic: reconstructing the Hunt mosaic from Palermo". Journal of Roman Archeology, vol. 15, pp. 264-274, 2002. 